Área Abierta. Revista de comunicación

audiovisual y publicitaria

ISSN: 2530-7592 / ISSNe: 1578-8393

http://dx.doi.org/10.5209/ARAB.62327

\title{
Síntomas y testigos de un cine en cambio
}

\section{Presentación: Bénédicte Brémard y José Luis Sánchez Noriega}

Dentro del proyecto de investigación "Sociedad, democracia y cultura en el cine español de la era socialista (1982-1996)", hemos venido profundizando en el cambio social que tiene lugar con el acceso al poder de la izquierda desde hacía medio siglo y en cómo nuestro cine trazaba una panorámica o establecía algún tipo de diagnóstico sobre una época llena de tensiones y contradicciones. Ese cambio conoce transformaciones decisivas: desde la brutal reconversión industrial que lleva al paro a miles de trabajadores al desarrollo de infraestructuras y la bonanza económica con la adhesión a la Unión Europea; de los resabios franquistas y el fallido golpe de Estado del 23-F a la consolidación de las libertades; de la austeridad y conciencia de clase de la izquierda a la cultura del pelotazo de la beautiful people.

No son menos radicales los cambios en el marco de la producción y exhibición del cine español: los ochenta muestran una caída en picado del número de espectadores y una desafección hacia las historias que cuentan nuestros cineastas, a pesar del look más internacional que logran las cuidadas producciones alentadas por Pilar Miró desde la Dirección General de Cinematografía. El vídeo, los nuevos canales de televisión y —ya al final del siglo_ - las plataformas digitales alteran los mecanismos habituales de amortización de las películas. Hay que esperar a una nueva generación de cineastas, bien entrados los noventa, para que el cine español se reencuentre con el público más joven y sensible hacia una cultura audiovisual que demanda nuevos géneros y tratamientos, más desinhibidos, con imágenes encaminadas a la fascinación antes que a la reflexión.

Una primera aportación de este proyecto $\mathrm{I}+\mathrm{D}+\mathrm{i}$ ha sido el libro Trayectorias, ciclos y miradas del cine español (1982-1996) (Barcelona, Laertes, 2017) donde se hacen análisis de un corpus de las ciento treinta y cinco películas más representativas y se abunda en el contexto político, histórico y social de la España del felipismo, se da cuenta de la política cinematográfica y se esbozan los temas, ciclos, géneros y estilos del cine español en esos años. Un segundo libro, Imaginarios y figuras en el cine de la postransición (Laertes, en prensa), resulta complementario a este número de Área Abierta en cuanto ambas publicaciones plantean diversos enfoques transversales y breves profundizaciones sobre películas (En construcción, Fresa y chocolate) y cineastas singulares (Bigas Luna, Guerín, Bollaín), soportes novelísticos y teatrales, representaciones de edades y conflictos sociales, tensiones de géneros (comedias de cine de barrio, melodrama, thriller), generación de mujeres cineastas, etc. Una tercera aportación, de carácter monográfico ha sido el estudio Universo Almodóvar (Madrid, Alianza Editorial, 2017) que abunda en el cineasta más carismático de esa época, auténtico auteur con una personalidad y una carrera que desbordan el marco peninsular para convertirlo en español universal. 
Obviamente, con estos trabajos no se trata de hacer una historia completa del cine español de los ochenta y noventa: nos conformamos con cierta cartografía del conjunto, que permita ulteriores profundizaciones, hecha desde un presente de veinte años después en el que la distancia permite juicios más ponderados. Junto a ese diseño hay trabajos específicos que quieren ser representativos de algunas características singulares del cine de estas décadas.

Este monográfico de Área Abierta consta de siete trabajos que se articulan claramente en tres bloques: a) profundización en los conflictos sociales y cómo el cine se ha hecho eco de la inmigración (Gordillo) o de otras situaciones de tensión social como la corrupción política y la cultura del pelotazo (Sánchez Noriega); b) representaciones de personas en los márgenes de la pirámide social: adolescentes (Brémard) y ancianos (Guarinos); y c) estudio de géneros desde cineastas concretos, como la comedia (Pérez Morán), el melodrama (Durán) y películas singulares (García Reyes), representativos del cine del período.

En el primer artículo se recorre la filmografía de Mario Camus de los noventa poniéndola en correlación con ciertos sucesos y, sobre todo, con la evolución de los gobiernos y el clima de degradación moral. En estas películas queda patente la renuncia a los valores de austeridad de la izquierda y la nueva fe en el enriquecimiento, la corrupción política que deja atrás víctimas inermes, la mentira y la impostura como mecanismos de manipulación, y la crítica al terrorismo desde la convicción de que la violencia siempre degrada al ser humano.

La segunda aportación del primer bloque de artículos se centra en el tratamiento de la inmigración en el cine español: La profesora Gordillo se vale de un elocuente caso de estudio para, a partir de una ficción de Montxo Armendáriz y de un documental de Llorenç Soler, mostrar cómo es posible un cine de la alteridad que sea respetuoso con la perspectiva cultural, social o, simplemente, humana del "otro". Aunque la filmografía más abundante vendrá en años sucesivos, los noventa son testigos de un cambio de focalización en la visión del extranjero, no necesariamente sospechoso ni conflictivo.

Las películas que representan distintas edades y condiciones de ciudadanos dan cuenta, en el caso de adolescentes y ancianos, de situaciones conflictivas y formas de marginación. El trabajo de Brémard focaliza su mirada en las figuraciones de los cuerpos (explotados, soñadores, autodestructivos, espectaculares o torturados) que aparecen en historias de adolescentes en las ficciones cinematográficas: edad y tipos inaprensibles, resbaladizos, en sus contradicciones.

El segundo trabajo de análisis sobre personajes cinematográficos teniendo en cuenta la variable de edad lo desarrolla la profesora Virginia Guarinos con una metodología rigurosa, habitual en sociología, pero menos frecuente en los film studies. Se plantea las representaciones de las personas mayores (ancianos en el lenguaje coloquial, "tercera edad" en el más políticamente correcto) en el cine y en qué medida estas se hacen eco del cambio social que está viviendo el país, con las políticas socialistas del Imserso. El resultado constata — al igual que sucede en otras áreas - un desajuste entre la realidad histórica y las ficciones cinematográficas, que funcionan cultivando tópicos en la construcción de los personajes ancianos.

Un tercer bloque de artículos aborda películas y géneros específicos. Un estudio sobre el cine español de los dos últimos decenios del siglo XX quedaría incompleto sin la referencia a las coproducciones con otros países que, a diferencia de otras épocas en las que predominaban los títulos en colaboración con Francia, Italia y otros 
países europeos, en este período las obras más significativas se rodarán en colaboración con América Latina, principalmente coproducciones con Argentina. Pero en los años 90 sobresale la cubano-hispano-mexicana Fresa y chocolate, de uno de los grandes cineastas cubanos, Tomás Gutiérrez Alea, que tuvo el acierto de ofrecer cierto diagnóstico sobre la fractura social que vivía la isla. En su documentado artículo, David García Reyes ofrece un estudio completo de una película rica en referencias literarias y la traslación de un cuento que es ella misma. Pero queda subrayado en este trabajo cómo la anécdota argumental alcanza la condición de categoría, al mostrar el tenue cambio del régimen hacia los disidentes.

En continuación con otros trabajos que también buscan el perfil de la sociedad que subyace a la comedia popular, el profesor Pérez Morán aporta un análisis de las películas españolas del felipismo de este género para rastrear la visión que difunden de las mentalidades, apuestas ideológicas, aspiraciones y conflictos sociales, diferencias de clase, estilos de vida, mutaciones de los valores morales, tensiones entre el ámbito rural y el urbano, etc. y, sobre todo, de figuras significativas, clichés sociales y estereotipos donde queda patente el vigente patriarcado que relega a un distante segundo plano a los personajes femeninos.

Finalmente, la tercera aportación es un estudio del melodrama nostálgico $-\mathrm{y}$ hasta reaccionario, cabría decir- de José Luis Garci a cargo del profesor Durán Manso. Garci ha tenido en los dos últimos decenios del siglo XX más importancia por su divulgación cinéfila en programas de televisión que comentaban películas sabiamente elegidas que por las propias cintas que rodó. Su cine en estos años hunde sus raíces en el cine clásico y viene muy marcado por el sentimiento de pérdida en los personajes masculinos, que se lamentan de las heridas abiertas por el paso del tiempo.

Los artículos del presente número monográfico de Área Abierta son resultado de los trabajos de los miembros del equipo investigador y del equipo de trabajo del I $+\mathrm{D}+\mathrm{i}$ del Ministerio de Economía y Competitividad (Secretaría de Estado de Investigación, Desarrollo e Innovación) titulado HAR2015-66457-P "Sociedad, democracia y cultura en el cine español de la era socialista (1982-1996)". 